\title{
ДИНАМІКА АКТИВНОСТІ ПРОЦЕСІВ ЛІПІДНОЇ ПЕРОКСИДАЦІЇ В ПІЗНІЙ ПЕРІОД КРАНІОСКЕЛЕТНОЇ ТРАВМИ ЗА УМОВ ХРОНІЧНОГО ГЕПАТИТУ ТА ЕФЕКТИВНІСТЬ КОРЕКЦІЇ АРМАДІНОМ
}

Вступ. Травматизм належить до актуальних медичних і соціальних проблем сьогодення. Останнім часом значно збільшилась вірогідність отримання травм на тлі супутніх дифузних захворювань печінки, частота яких постійно зростає. Одним з об'єктів системної відповіді організму на травмує печінка, в якій унаслідок травматичної хвороби суттєво посилюються процеси ліпідної пероксидації.

Мета дослідження - з'ясувати динаміку активності процесів ліпідної пероксидації в печінці в пізній період краніоскелетної травми за умов хронічного гепатиту та оцінити ефрективність корекції армадіном.

Методи дослідження. Експерименти виконано на 136 нелінійних білих щурах-самцях масою 200-220 2. У 1-й дослідній групі наносили краніоскелетну травму, в 2-й - аналогічну травму наносили після моделювання хронічного гепатиту (С. P. Siegers ma ін., 1982), у 3-й - моделювали хронічний гепатит, наносили травму і з метою корекції щоденно внутрішньочеревно вводили армадін у дозі 20 мг/ка, починаючи з 15-ї доби після травматичного періоду. Тварин виводили з експерименту через 14, 21, 28 і 35 діб після нанесення травми. Контрольними стали групи інтактних тварин та щурів із хронічним гепатитом. У печінці піддослідних тварин визначали вміст реагентів до тіобарбітурової кислоти (ТБК-активних продуктів пероксидного окиснення ліпідів).

Результати й обговорення. Моделювання краніоскелетної травми супроводжувалось активацією в печінці процесів ліпідної пероксидації. Вміст у печінці ТБК-активних продуктів пероксидного окиснення ліпідів протягом усього терміну експерименту був істотно більшим, ніж у контрольних групах. За умов нанесення краніоскелетної травми на тлі супутнього хронічного гепатиту вміст ТБК-активних продуктів пероксидного окиснення ліпідів суттєво перевищував такий у групі травмованих тварин без цього захворювання. Застосування армадіну сприяло зменшенню інтенсивності ліпідної пероксидації в печінці при нанесенні краніоскелетної травми на тлі хронічного гепатиту. Порівняно з тваринами без корекції результат виявився статистично вірогідним через 21 і 35 діб.

Висновки. Моделювання краніоскелетної травми на тлі хронічного гепатиту в період пізніх проявів травматичної хвороби зумовлює тривале посилення активності процесів ліпідної пероксидації в печінці, яке до 35-ї доби експерименту не досягає рівня контролю. Застосування армадіну, порівняно з тваринами без корекції, викликає зниження вмісту в печінці ТБК-активних продуктів пероксидного окиснення ліпідів, починаючи з 21-ї доби експерименту.

КЛЮчОВІ СЛОВА: краніоскелетна травма; травматична хвороба; пізній період; печінка; ліпідна пероксидація; армадін.

ВСТУП. Травматизм належить до актуальних медичних і соціальних проблем сьогодення. За даними ВОО3, у світі від травм щорічно гине до 2 млн осіб і понад 45 млн осіб стають інвалідами. Уже сьогодні травматизм належить до основних причин смерті осіб працездатного віку й, за прогнозами розвинених країн, невдовзі охопить усі вікові групи [1].

У структурі тяжких травм провідне місце займають поєднані ураження, за яких одночасно ушкоджуються дві й більше анатомічних ділянки тіла, що зумовлюють розвиток травма(с) О. О. Прохоренко, Г. Ю. Цимбалюк, 2021. тичної хвороби з летальністю до 80 \% [2]. Небезпечним для життя ускладненням травматичної хвороби є вторинне ураження органів 3 формуванням поліорганної дисфункції і недостатності, яка стає основною причиною загибелі організму [3].

Одним з об'єктів системної відповіді організму на травму є печінка. У численних публікаціях показано, що внаслідок отримання тяжкої скелетної травми в цьому органі виникають виражені морфоорункціональні порушення, знижується детоксикаційна фрункція гепатоцитів, це поглиблює перебіг травматичної хвороби [4]. 
В окремих публікаціях розглядають питання щодо перебігу травматичної хвороби за умов хронічного гепатиту, частота якого в загальній структурі хронічних захворювань органів травлення становила $5 \%$, показник поширеності 944 на 100 тис. дорослого населення [5]. Зокрема, йдеться про те, що в ранній період поєднаної травми на тлі хронічного гепатиту спостерігають інтенсифікацію ліпідної пероксидації, яка проявляється збільшенням вмісту в печінці первинних і вторинних продуктів, що досягає максимуму через 3 доби, залишається на такому ж рівні до 7-ї доби та суттєво вищий, ніж у травмованих тварин без хронічного гепатиту [6]. Однак динаміку активності процесів ліпідної пероксидації в період пізніх проявів травматичної хвороби на тлі хронічного гепатиту вивчено недостатньо. Актуальність її дослідження зумовлена тим, що переокиснення протеїнів та ліпідів клітинних мембран належить до універсальних механізмів ушкодження і за умов травматичної хвороби $€$ пусковим чинником розвитку поліорганної недостатності [7].

Одним із перспективних препаратів, які поєднують як антигіпоксичні, так і антиоксидантні властивості, є армадін - 3-оксипіридин 2-етил6-метил-3-гідроксиперидину сукцинат [8]. Це комплекс емоксипіну (похідне оксипіридину) 3 бурштиновою кислотою (сукцинат), який використовують для корекції неврологічної і серцево-судинної патології [9]. Результати досліджень показали, що препарат швидко проникає у клітини, а потім дисоціює в цитозолі на 2 компоненти. Кожен з них чинить самостійний позитивний вплив. Емоксипін сприяє пригніченню вільнорадикальних процесів. Бурштинова кислота дозволяє підтримувати процеси утворення високоенергетичних сполук [10]. Метаболічна дія препарату не тільки в центральній нервовій системі, але й у перифреричних органах ставить армадін у ряд перспективних засобів системної корекції за умов травми і хронічного гепатиту, що вимагало спеціального дослідження.

Мета дослідження - з'ясувати динаміку активності процесів ліпідної пероксидації в печінці в пізній період краніоскелетної травми (КСТ) за умов хронічного гепатиту та оцінити ефективність корекції армадіном.

МЕТОДИ ДОСЛІДЖЕННЯ. Експерименти виконано на 136 нелінійних білих щурах-самцях масою 200-220 г, яких утримували на стандартному раціоні віварію. Усіх тварин поділили на 5 груп: 2 контрольних і 3 дослідних. У 1-й контрольній групі (КГ-1) моделювали хронічний гепатит за методом С. P. Siegers та ін. (1982) шляхом внутрішньочеревного введення 50 \% олійного розчину тетрахлорметану в дозі 0,2 мл к $^{-1} 2$ рази на тиждень протягом 4 тижнів із заміною питної води $5 \%$ розчином етанолу [11]. У 2-й контрольній групі (КГ-2) інтактним тваринам аналогічно вводили оливкову олію в еквівалентній дозі. Тварин виводили з експерименту через 4 тижні. У 1-й дослідній групі (ДГ-1) протягом 1 місяця імітували моделювання хронічного гепатиту замість токсикантів уводили фрізіологічний розчин, а далі моделювали КСТ: за умов тіопентал-натрієвого наркозу (40 мг $\left.\cdot \mathrm{r}^{-1}\right)$ послідовно викликали черепно-мозкову травму середнього ступеня тяжкості шляхом нанесення дозованого удару по черепу в точці на 5 см допереду від міжвушної лінії з енергією 0,38 Дж та закритий перелом обох стегон шляхом нанесення дозованого механічного ушкодження кожному стегну ударним пристроєм із клиноподібною насадкою 3 енергією 0,64 Дж [12]. У 2-й дослідній групі (ДГ-2) моделювали КСТ після відтворення хронічного гепатиту. В 3-й дослідній групі (ДГ-3) викликали хронічний гепатит, моделювали КСТ і $з$ метою корекції щоденно внутрішньочеревно вводили 2-етил-6-метил-3-гідроксипіридину сукцинат (Армадін, виробництво ТОВ Наукововиробнича фрірма "Мікрохім", Україна) в дозі 20 мг/кг у 0,5 мл води для ін'єкцій, починаючи 3 15-ї доби після нанесення КСТ. Усі експерименти було проведено відповідно до Європейської конвенції про захист хребетних тварин, що використовуються для дослідних та інших наукових цілей (Страсбург, 1986) і Загальних етичних принципів експериментів на тваринах, схвалених на I Національному конгресі з біоетики (Київ, 2001).

Тварин дослідних груп виводили з експерименту за умов тіопентал-натрієвого наркозу через 14, 21, 28 і 35 діб після нанесення травми. У печінці щурів контрольних та дослідних груп визначали вміст реагентів до тіобарбітурової кислоти (ТБК-активних продуктів пероксидного окиснення ліпідів (ПОЛ)), які належать до скринінгових показників процесів ліпопероксидації [13]. Вірогідність відмінностей визначали з використанням непараметричного критерію Манна - Уїтні.

РЕЗУЛЬТАТИЙ ОБГОВОРЕННЯ. ДосЛіДЖеНня показали, що під впливом КСТ (ДГ-1) вміст ТБК-активних продуктів ПОЛ у печінці через 14 діб експерименту був істотно вищим, ніж у КГ-1 (на $75,4 \%, p<0,05)$. У подальшому показник поступово знижувався, досягнув мінімальної величини через 35 діб, що виявилося статистично вірогідно меншим порівняно 3 14-ю, 21-ю і 28-ю добами спостереження $(p<0,05)$. Однак через 35 діб він не досягнув рівня КГ-1 і залишився на 21,4 \% більшим $(p<0,05)$. 
Нанесення КСТ на тлі хронічного гепатиту (ДГ-2), порівняно з КГ-2, теж супроводжувалося статистично значущим зростанням вмісту ТБК-активних продуктів ПОЛ у печінці, проте максимум підвищення показника відмічали через 21 добу спостереження (на 47,1 \%, p<0,05). У подальшому він теж знижувався i, починаючи 3 28-ї доби, досягав найменшого рівня, що виявилося статистично вірогідним порівняно 3 14-ю та 21-ю добами, проте на 16,0 \% перевищувало показник КГ-2 $(\mathrm{p}<0,05)$. Практично на такому ж рівні показник залишався і до 35-ї доби експерименту.

Порівняння ДГ-1 і ДГ-2 показало, що нанесення КСТ на тлі хронічного гепатиту (ДГ-2) в усі терміни посттравматичного періоду супроводжувалося статистично вірогідним збільшенням вмісту ТБК-активних продуктів ПОЛ у печінці порівняно з ДГ-1: через 14 діб - на 12,9\%, через 21 добу - на 38,5 \%, через 28 діб - на 10,7 \%, через 35 діб - на 47,8 \% ( $\left.\mathrm{p}_{1-2}<0,05\right)$.

Застосування з корегувальною метою армадіну в групі тварин із КСТ, яку було нанесено на тлі хронічного гепатиту (ДГ-3), зумовлювало суттєве зменшення вмісту ТБК-активних продуктів ПОЛ порівняно зі щурами без корекції (ДГ-2). Через 21 і 35 діб результат виявився статистично значущим (відповідно, на 21,0 та 18,0 \%, $\left.\mathrm{p}_{2-3}<0,05\right)$. Незважаючи на корекцію, показник у всі терміни спостереження перевищував величину ДГ-1 ( $\left.p_{1-3}<0,05\right)$, проте через 28 і 35 діб досягав рівня КГ-2 (p>0,05). У динаміці в групі тварин, яким моделювали хронічний гепатит, наносили КСТ і проводили корекцію армадіном, відмічали найвищий вміст ТБК-активних продук- тів ПОЛ через 14 діб з наступним зниженням до закінчення експерименту. Через 35 діб показник ставав істотно меншим порівняно з попередніми термінами спостереження $(\mathrm{p}<0,05)$ (табл.).

Отримані результати свідчать про те, що моделювання КСТ навіть у період пізніх проявів травматичної хвороби супроводжувалось активацією в печінці процесів ліпідної пероксидації, що виявляли за вмістом у печінці ТБК-активних продуктів ПОЛ. Показник був максимальним через 14 діб з наступним зниженням до 35-ї доби, яке не досягало рівня контролю. Ці дані вказують на тривалий у часі вплив патогенних механізмів, зумовлених травмою, які супроводжуються надлишковим утворенням у печінці активних форм оксигену й активацією вільнорадикальних процесів. Останні, завдяки переоксиненню протеїнів і ліпідів клітинних мембран, здатні викликати порушення мембранозалежних фрункцій. Подібні результати отримали й інші автори, які досліджували період пізніх проявів травматичної хвороби $[14,15]$. Тривалу активацію ліпідної пероксидації автори пов'язують також із недостатністю ензимної і неензимної ланок антиоксидантного захисту, ключові компоненти якої синтезує печінка [16, 17].

Моделювання хронічного гепатиту зумовлювало стале підвищення, порівняно з контролем, вмісту ТБК-активних продуктів ПОЛ, що є характерною ознакою даного патологічного процесу [18]. Нанесення на цьому тлі КСТ викликало посилення процесів ліпідної пероксидації, очевидно, внаслідок нашарування патогенних механізмів як хронічного гепатиту, так і травматичної хвороби. Однак амплітуда зростання була

Таблиця - Вміст ТБК-активних продуктів пероксидного окиснення ліпідів у печінці

в динаміці пізнього періоду краніоскелетної травми на тлі хронічного гепатиту та ефективність корекції армадіном ((Me (LQ; UQ) - медіана (нижній і верхній квартилі))

\begin{tabular}{|c|c|c|c|c|c|}
\hline \multirow{2}{*}{$\begin{array}{c}\text { Дослідна } \\
\text { група }\end{array}$} & \multirow{2}{*}{$\begin{array}{c}\text { Контрольна } \\
\text { група }\end{array}$} & \multicolumn{4}{|c|}{ "Політравма } \\
\hline & & 14-та доба & 21-ша доба & 28-ма доба & 35-та доба \\
\hline 1-ша (KCT) & $\begin{array}{c}25,37 \\
(5,17 ; 5,61) \\
n=6\end{array}$ & $\begin{array}{c}9,42^{\star} \\
(9,26 ; 9,56) \\
n=9\end{array}$ & $\begin{array}{c}9,01^{\star} \\
(8,86 ; 9,14) \\
n=8\end{array}$ & $\begin{array}{c}8,15^{\star} \\
(7,48 ; 8,68) \\
n=8\end{array}$ & $\begin{array}{c}6,52^{*} \\
(6,38 ; 7,07) \\
n=7\end{array}$ \\
\hline $\begin{array}{l}\text { 2-га (КСТ+хронічний } \\
\text { гепатит) }\end{array}$ & $\begin{array}{c}18,48 \\
(7,63 ; 8,76) \\
n=8\end{array}$ & $\begin{array}{c}10,64^{\star} \\
(10,43 ; 10,78) \\
n=7\end{array}$ & $\begin{array}{c}12,48^{\star} \\
(12,36 ; 12,97) \\
n=6\end{array}$ & $\begin{array}{c}9,84^{*} \\
(9,22 ; 10,15) \\
n=6\end{array}$ & $\begin{array}{c}9,64^{*} \\
(9,22 ; 10,00) \\
n=6\end{array}$ \\
\hline $\begin{array}{l}\text { 3-тя (КСТ+хронічний } \\
\text { гепатит+корекція }\end{array}$ & & $\begin{array}{c}10,03^{*} \\
(9,88 ; 10,35) \\
n=8\end{array}$ & $\begin{array}{c}9,86^{\star} \\
(9,72 ; 10,71) \\
n=8\end{array}$ & $\begin{array}{c}9,18 \\
(8,80 ; 9,64) \\
n=8\end{array}$ & $\begin{array}{c}7,90 \\
(7,74 ; 8,56) \\
n=8\end{array}$ \\
\hline$p_{1-2}$ & & $<0,05$ & $<0,05$ & $<0,05$ & $<0,05$ \\
\hline $\mathrm{p}_{1-3}$ & & $<0,05$ & $<0,05$ & $<0,05$ & $<0,05$ \\
\hline$p_{2-3}$ & & $>0,05$ & $<0,05$ & $>0,05$ & $<0,05$ \\
\hline
\end{tabular}

Примітки:

1. 1,2 - відповідно, КГ-1, КГ-2.

2. * - відмінності стосовно контрольної групи статистично вірогідні $(p<0,05)$.

3. $\mathrm{p}_{1-2}$ - вірогідність відмінностей між ДГ-1 і дГ-2; $\mathrm{p}_{1-3}$ - вірогідність відмінностей між ДГ-1 і ДГ-3; $\mathrm{p}_{2-3}-$ вірогідність відмінностей між ДГ-2 і ДГ-3. 
істотно меншою, ніж за умов моделювання лише КСТ. Отже, на тлі хронічного гепатиту динаміка досліджуваного показника $є$ більш інтертною, що вказує на нижчу реакційну здатність паренхіми ураженої печінки до впливу патогенних чинників травматичної хвороби. Можна припустити, що за цих умов навіть незначні за амплітудою порушення ліпопероксидації в динаміці травматичної хвороби свідчать про наявність глибоких некробіотичних змін у гепатоцитах. Однаку клініці такі порушення можна трактувати як хибнопозитивний результат, що слід враховувати в комплексній інтенсивній терапії травматичної хвороби.

Застосування армадіну сприяло зменшенню інтенсивності ліпідної пероксидації в печінці за умов нанесення КСТ на тлі хронічного гепатиту. Порівняно $з$ тваринами без корекції результат виявився статистично вірогідним через 21 і
35 діб. Отриманий результат вказує на виражений антиоксидантний вплив досліджуваного препарату, який, очевидно, має системний характер та здатний нівелювати прооксидантні патогенні механізми як хронічного гепатиту, так і модельованої травми. Важливо відмітити, що статистично значуще зниження вмісту ТБК-активних продуктів ПОЛ мало коливальний характер, що, з позиції саногенно-патогенних співвідношень як фрорми адаптації організму до впливу патогенного чинника [19], вказує на поглиблення препаратом ендогенних саногенних механізмів, спрямованих на зниження проявів прооксидантних механізмів (рис.).

Таким чином, армадін $є$ перспективним антиоксидантним засобом за умов хронічного гепатиту і КСТ у період пізніх проявів травматичної хвороби, що вимагає подальшого поглибленого доклінічного вивчення.

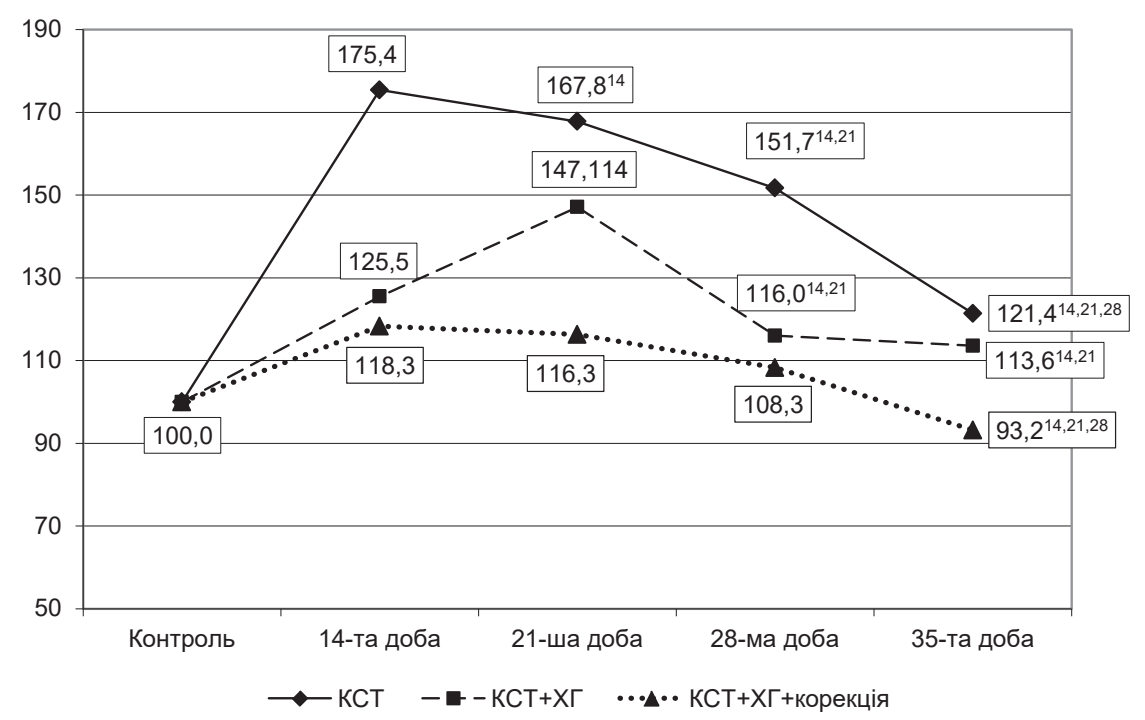

Рис. Динаміка вмісту ТБК-активних продуктів пероксидного окиснення ліпідів у печінці (у відсотках до рівня контролю) в динаміці краніоскелетної травми на тлі хронічного гепатиту та ефективність корекції армадіном.

Примітка: ${ }^{14,21,28}$ - показники стосовно 14-ї, 21-ї і 28-ї діб спостереження статистично вірогідні $(\mathrm{p}<0,05)$.

ВИСНОВКИ. 1. Моделювання краніоскелетної травми на тлі хронічного гепатиту в період пізніх проявів травматичної хвороби зумовлює тривале посилення процесів ліпідної пероксидації в печінці, яке до 35-ї доби експерименту не досягає рівня контролю та в усі терміни супроводжується статистично вірогідним збільшенням вмісту в печінці ТБК-активних продуктів пероксидного окиснення ліпідів порівняно 3 тваринами без хронічного гепатиту.

2. Застосування армадіну, починаючи 3 15-ї доби після нанесення краніоскелетної травми на тлі хронічного гепатиту, порівняно $з$ тваринами без корекції, викликає зниження вмісту в печінці ТБК-активних продуктів пероксидного окиснення ліпідів, що статистично значуще через 21 і 35 діб експерименту. 


\section{СПИСОК ЛІТЕРАТУРИ}

1. Management of the patients with blunt renal trauma: 20 years of clinical experience / L. P. Sarychev, Y. V. Sarychev, H. L. Pustovoyt [et al.] // Wiad. Lek. 2018. - 71, Issue 3, pt. 2. - P. 719-722.

2. Гур'єв С. О. Аналіз безпосередіх причин смерті у постраждалих із політравмою та пошкодженням скелета / С. О. Гур'єв, А. Ю. Філь, О. М. Танасієнко // Травма. - 2015. - 16, № 4. - С. 7-10.

3. Гудима А. А. Особливості поглинально-видільної та глікогенсинтезувальної функцій печінки в ранній період краніоскелетної травми та їх корекція клітинною терапією / А. А. Гудима, Т. А. Заєць // Вісн. наук. дослідж. - 2014. - № 2. - С. 97-99.

4. Козак Д. В. Особливості функціонального стану печінки в динаміці раннього посттравматичного періоду політравми / Д. В. Козак // Biomed. Biosoc. Anthropology. - 2013. - № 20. - C. 97-99.

5. Щербина М. Б. Інновації в лікуванні хронічних медикаментозних та алкогольних гепатитів / М. Б. Щербина // Гастроентерологія. - 2012. - № 429. - С. 48-50.

6. Близнюк Р. В. Динаміка показників ліпідної пероксидації та антиоксидантного захисту тканини печінки в ранній період після нанесення політравми у тварин з хронічним гепатитом / Р. В. Близнюк // Здобутки клініч. і експерим. медицини. - 2015. - № 2-3. C. $32-36$

7. Гудима А. А. Антиоксидантно-прооксидантний та цитокіновий баланс у пізній період комбінованої травми в експерименті / А. А. Гудима, Т. В. Кащак, К. В. Шепітько // Світ медицини та біології. - 2019. № 1 (67). - C. 42-47.

8. Functional and biochemical parameters of erythrocytes during mexicor treatment in posttraumatic period after experimental blood loss and combined traumatic brain injury / A. V. Deryugina, A. V. Shumilova, E. S. Filippenko [et al.]. Bull. Exp. Biol. Med. - 2017. No. 164. - P. 26-29. DOI: 10.1007/s10517-017-3918-4.

9. Применение цитопротективной терапии мексикором у пациентов после радиочастотной аблации фрибрилляции предсердий с целью профилактики ранних послеоперационных аритмий / Н. В. Лапшина А. С. Лотина, Ю. А. Яблонская [и др.] // Вестн. анестезиологии. - 2018. - № 91. - С. 48-51.

10. Study of dose-dependent efect of 2-ethyl-6methyl-3 hydroxypyridine succinate on the contractile function of isolated rat heat / O. G. Kesarev, L. M. Da- nilenko, M. V. Pokrovskii [et al.] // Res. Result. Pharmacol. Clin. Pharmacol. - 2017. - No. 3. - P. 3-9. DOI: 10.18413/ 2500-235X-2017-3-1-3-9.

11. Effects of dithiocarb and (+)cyanidanol-3 on the $\mathrm{CCL}_{4}$ alcohol induced fibrosis of rat liver / C. P. Siegers, V. Voipel, G. Schel [et al.] // Connective Tissue Norn. and Fibrotis. Hum. Liver. - 1982. - No. 3. - P. 244-245.

12. Пат. на корисну модель № 81107 Україна, МПК (2006.01) G 09 В 23/28. Спосіб моделювання політравми / Левчук Р. Д., Михайлюк І. А., Мерлєв Д. І. ; заявник і патентовласник Терноп. держ. мед. ун-т імені І. Я. Горбачевського. - № u 201213575 ; заявл. 27.11 .12 ; опубл. 25.06.13, Бюл. № 12.

13. Доклінічні дослідження лікарських засобів : метод. рек. / за ред. О. В. Стефанова. - К. : Авіцена, 2001. -528 c.

14. Серватович А. М. Динаміка порушень процесів ліпідної пероксидації в період пізніх проявів травматичної хвороби після краніоскелетної травми та ефективність корекції фрітозбором / А. М. Серватович // Вісн. наук. дослідж. - 2015. - № 4. - С. 106-109.

15. Придруга С. М. Динаміка вмісту продуктів пероксидного окиснення ліпідів в печінці щурів у період пізніх проявів траватичної хвороби та корекції відхилень тіотриазоліном / А. М. Серватович // Вісн. проблем біології і медицини. -2012. - 1, № 4. - С. 244-247.

16. Servatovych A. M. The role of antioxidant defense disturbances in pathogenesis of the late manifestations of traumatic disease after cranio-skeletal injury and effectiveness of its correction by phytomixture / A. M. Servatovych, A. A. Gudyma // J. Educ. Health Sport. - 2015. - 5, Issue 12. - P. 271-278. - Access mode: http://ojs.ukw.edu.pl/index.php/johs/article/ view/2015\%3B5(12)\%3A271-278.

17. Придруга С. М. Особливості антиоксидантного захисту в патогенезі проявів травматичної хвороби та їх корекція / С. М. Придруга // Мед. хімія. - 2013. 15, № 1 (54). - С. 85-89.

18. Jaeschke $H$. Reactive oxygen and mechanism of inflammatory liver injury: Present concept / H. Jaeschke // Gastorenterol. Hepatol. - 2011. - 26, Supp I. P. 173-179.

19. Козак Д. В. Антиоксидантно-прооксидантний баланс у тканині печінки в динаміці політравми / Д. В. Козак // Шпит. хірургія. - 2013. - № 4 (64). C. $40-44$.

\section{REFERENCES}

1. Sarychev, L.P., Sarychev, Y.V., Pustovoyt, H.L., Sukhomlin, S.A., \& Suprunenko, S.M. (2018). Management of the patients with blunt renal trauma: 20 years of clinical experience. Wiad. Lek., 71 (3 pt. 2), 719-722.

2. Huriev, S.O., Fil, A.Yu., \& Tanasienko, O.M. (2015). Analysis of immediate causes of death in victims with polytrauma and skeletal damage. Trauma, 16 (4), 7-10 [in Ukrainian].

3. Hudyma, A.A., \& Zayets, T.A. (2014). Features of absorption-excretory and glycogen-synthesizing functions of the liver in the early period of cranioskeletal trauma and their correction by cell therapy. Bull. Sci. Res., 2, 97-99.

4. Kozak, D.V. (2013). Features of the functional state of the liver in the dynamics of the early post-traumatic period of trauma. Biomed. Biosoc. Anthropology, 20, 97-99 [in Ukrainian].

5. Shcherbina, M.B. (2012). Innovations in the treatment of chronic drug and alcoholic hepatitis. Gastroenterology, 429, 48-50. 
6. Blyzniuk, R.V. (2015). Dynamics of lipid peroxidation and antioxidant protection indicators of liver tissue in the early period after the application of multiple injuries in animals with chronic hepatitis. Achievements of Clinical and Experimental Medicine, 2-3, 32-36. DOI: 10.11603/ 1811-2471.2015.v23.i2-3.5233.

7. Hudyma, A.A., Kashchak, T.V., \& Shepitko, K.V. (2019). Antioxidant-prooxidant and cytokine balance in the late period of combined trauma in the experiment. World of Medicine and Biology, 1 (67), 42-47. DOI: 10.26724/2079-8334-2019-1-67-42 [in Ukrainian].

8. Deryugina, A.V., Shumilova, A.V., Filippenko, E.S., Galkina, Y.V., Simutis, I.S., \& Boyarinov, G.A. (2017) Functional and biochemical parameters of erythrocytes during mexicor treatment in posttraumatic period after experimental blood loss and combined traumatic brain injury. Bull Exp. Biol. Med., 164, 26-29. DOI: 10.1007/ s10517-017-3918-4.

9. Lapshina, N.V., Lotina, A.S., Yablonskaya, Yu.A., Burnazyan, S.E., \& Mullova, I.S. (2018). Cytoprotective therapy with mexicor in patients after radiofrequency ablation of atrial fibrillation to prevent early post-procedural arrhythmias. Anesthesiol. Bull., 91, 48-51 [in Russian]

10. Kesarev, O.G., Danilenko, L.M., Pokrovskii, M.V., Timokhina, A.S., \& Khavanskii, A.V. (2017). Study of dose-dependent efect of 2-ethyl-6-methyl-3 hydroxypyridine succinate on the contractile function of isolated rat heat. Res. Result. Pharmacol. Clin. Pharmacol., 3, 3-9. DOI: 10.18413/ 2500-235X-2017-3-1-3-9.

11. Siegers, C.P., Voipel, V., Schel, G., \& Younes, M. (1982). Effects of dithiocarb and (+)cyanidanol-3 on the $\mathrm{CCl}_{4}$ alcohol induced fibrosis of rat liver. Connective Tissue Norn. and Fibrotis. Hum. Liver, 3, 244-245. DOI: 10.1007/BF01965096.

12. Levchuk, R.D., Mikhailyuk, I.A., \& Merlev, D.I. (2013). Pat. Ukraine for utility model No. 81107 IPC
(2006.01) G 09 B 23/28. The method of polytrauma modeling. I. Horbachevsky Ternopil National Medical University inventors and assignee. No. u 201213575 stated. 27.11.2012; publ. 25.06.13, Bull. No. 12 [in Ukrainian].

13. Stefanov, O.V. (Ed.). (2001). Preclinical studies of drugs: guidelines. Kyiv: Avicenna [in Ukrainian].

14. Servatovych, A.M. (2015). Dynamics of disturbance processes of lipid peroxidation during the late manifestations of traumatic disease after cranio-skeletal injury and effectiveness of its correction by phytomixture. Bull. Sci. Res., 4, 106-109. DOI: 10.11603/1681276X.2015.4.5661 [in Ukrainian].

15. Prydruha, S.M. (2012). Dynamics of the content of lipid peroxidation products in the liver of rats during the late manifestations of traumatic disease and correction of deviations by thiotriazoline. Bull. Probl. Biol. Med., 1 (4), 244-247 [in Ukrainian].

16. Servatovych, A.M., \& Gudyma, A.A. (2015). The role of antioxidant defense disturbances in pathogenesis of the late manifestations of traumatic disease after cranio-skeletal injury and effectiveness of its correction by phytomixture. J. Educ. Health Sport, 5 (12), 271-278. Retrieved from: http://ojs.ukw.edu.pl/index.php/johs/article/view/2015\%3B5(12)\%3A271-278.

17. Prydruha, S.M. (2013). Peculiarities of antioxidant protection in the pathogenesis of traumatic disease manifestations and their correction. Med. Chem., 15, 1 (54), 85-89 [in Ukrainian].

18. Jaeschke, H. (2011). Reactive oxygen and mechanism of inflammatory liver injury: Present concept. Gastorenterol. Hepatol., 26, I, 173-179.

19. Kozak, D.V. (2013). Antioxidant-prooxidant balance in liver tissue in the dynamics of the field of injury. Hospital Surg., 4 (64), 40-44 [in Ukrainian].

O. O. Prokhorenko, H. Yu. Tsymbaliuk I. HORBACHEVSKY TERNOPIL NATIONAL MEDICAL UNIVERSITY

\section{DYNAMICS OF THE ACTIVITY OF LIPID PEROXIDATION PROCESSES IN LATE PERIOD OF CRANIOSKELETAL INJURY IN CASE OF CHRONIC HEPATITIS AND THE EFFECTIVENESS OF CORRECTION WITH ARMADINE}

\section{Summary}

Introduction. Currently, injuries are considered as relevant medical and social problem of the nowadays. Recently, the probability of developing traumatic disease has increased significantly based on the background of concomitant diffuse liver disease, the frequency of which is constantly increasing. One of the objects of the body's systemic response to injury is the liver, where lipid peroxidation is significantly enhanced due to traumatic disease.

The aim of the study - to investigate the dynamics of lipid peroxidation processes in late period of cranioskeletal trauma (CST) in case of chronic hepatitis and the effectiveness of correction with armadine.

Research Methods. The experiments were performed on 136 nonlinear white male rats weighting 200-220 g. In the first experimental group (EG-1) after the modelling of chronic hepatitis (Siegers C. P. et al., 1982), cranioskeletal trauma (CST) was simulated. In the second experimental group (EG-2) only CST was modeled. In the third study group (EG-3), chronic hepatitis was induced, CST was simulated and armadine at a dose of $20 \mathrm{mg} / \mathrm{kg}$ was 
administered intraperitoneally every day for correction starting from 15 days after CST. Animals of the experimental groups were removed from the experiment 14, 21, 28 and 35 days after injury. In the control and experimental groups, the content of reagents for thiobarbituric acid (TBA-active products of LPO) was determined in the liver.

Results and Discussion. Modelling of CST in the period of late manifestations of traumatic disease is accompanied by activation of lipid peroxidation processes in the liver. The content of TBA-active products of LPO in the liver throughout the experiment was significantly higher than in the control group. Under the conditions of application of CST with the concomitant chronic hepatitis, the content of TBA-active products of LPO in the liver increased and significantly exceeded the group of injured animals without concomitant chronic hepatitis. The use of armadine helped to reduce the intensity of lipid peroxidation in the liver under the conditions of CST on the background of chronic hepatitis. Compared with animals without correction, the result was statistically significant after 21 and 35 days.

Conclusions. Modeling of CST on the background of chronic hepatitis in the period of late manifestations of traumatic disease causes a prolonged increase in the activity of lipid peroxidation in the liver, which up to 35 days of the experiment does not reach the level of control. The use of armadine compared with animals without correction causes a decrease in the content of TBA-active products of the liver starting from the second day of the experiment.

KEY WORDS: cranioskeletal injury; traumatic disease; late period; lipid peroxidation; armadine.

Отримано 04.11.21

Адреса для листування: О. О. Прохоренко, Тернопільський національний медичний університет імені І. Я. Горбачевського мО3 України, майдан Волі, 1, Тернопіль, 46001, Україна, e-mail: uszd.neomed@gmail.com. 